Research article

Open Access

\title{
A candidate molecular signature associated with tamoxifen failure in primary breast cancer
}

\author{
Julie A Vendrell1,2,3,4,5,6, Katherine E Robertson7*, Patrice Ravel ${ }^{8 *}$, Susan E Bray ${ }^{5}$, Agathe Bajard ${ }^{9}$, \\ Colin A Purdie 5 , Catherine Nguyen ${ }^{10}$, Sirwan M Hadad5 ${ }^{5}$, Ivan Bieche ${ }^{11}$, Sylvie Chabaud ${ }^{9}$, \\ Thomas Bachelot ${ }^{12}$, Alastair M Thompson ${ }^{5}$ and Pascale A Cohen ${ }^{1,2,3,4,6}$
}

\author{
1 Université de Lyon, 69008 Lyon, France \\ 2Université de Lyon, Lyon 1, ISPB, Faculté de Pharmacie de Lyon, 69008 Lyon, France \\ 3INSERM, U590, 69008 Lyon, France \\ ${ }^{4}$ Centre Léon Bérard, FNCLCC, 69373 Lyon, France \\ 5Department of Surgery and Molecular Oncology, Ninewells Hospital and Medical School, University of Dundee, Dundee DD1 9SY, UK \\ ${ }^{6}$ CNRS UMR 5160, Centre de Pharmacologie et Biotechnologie pour la Santé, Faculté de Pharmacie, 34090 Montpellier, France \\ ${ }^{7}$ Division of Pathology and Neuroscience, Ninewells Hospital and Medical School, University of Dundee, Dundee DD1 9SY, UK \\ ${ }^{8}$ Centre de Biochimie Structurale, CNRS, INSERM, Université Montpellier I, 34090 Montpellier, France \\ ${ }^{9}$ Centre Léon Bérard, FNCLCC, Unité de Biostatistique et d'Evaluation des Thérapeutiques, 69373 Lyon, France \\ 10INSERM ERM206, Laboratoire TAGC, Université d'Aix-Marseille II, 13288 Marseille Cedex 9, France \\ 11 INSERM U735, Centre René Huguenin, FNCLCC, 92210 St-Cloud, France \\ ${ }^{12}$ Centre Léon Bérard, FNCLCC, Département de Médecine, 69373 Lyon, France \\ ${ }^{*}$ Contributed equally
}

Corresponding author: Pascale A Cohen, pascale.cohen@recherche.univ-lyon1.fr

Received: 28 Feb 2008 Revisions requested: 7 Apr 2008 Revisions received: 13 Oct 2008 Accepted: 17 Oct 2008 Published: 17 Oct 2008

Breast Cancer Research 2008, 10:R88 (doi:10.1186/bcr2158)

This article is online at: http://breast-cancer-research.com/content/10/5/R88

(C) 2008 Vendrell et al.; licensee BioMed Central Ltd.

This is an open access article distributed under the terms of the Creative Commons Attribution License (http://creativecommons.org/licenses/by/2.0), which permits unrestricted use, distribution, and reproduction in any medium, provided the original work is properly cited.

\begin{abstract}
Introduction Few markers are available that can predict response to tamoxifen treatment in estrogen receptor (ER)positive breast cancers. Identification of such markers would be clinically useful. We attempted to identify molecular markers associated with tamoxifen failure in breast cancer.

Methods Eighteen initially ER-positive patients treated with tamoxifen requiring salvage surgery (tamoxifen failure [TF] patients) were compared with 17 patients who were disease free 5 years after surgery plus tamoxifen adjuvant therapy (control patients). cDNA microarray, real-time quantitative PCR, and immunohistochemistry on tissue microarrays were used to generate and confirm a gene signature associated with tamoxifen failure. An independent series of 33 breast tumor samples from patients who relapsed $(n=14)$ or did not relapse ( $n=19)$ under tamoxifen treatment from a different geographic location was subsequently used to explore the gene expression signature identified.
\end{abstract}

Results Using a screening set of 18 tumor samples (from eight control patients and 10 TF patients), a 47-gene signature discriminating between TF and control samples was identified using cDNA arrays. In addition to $E S R 1 / E R \alpha$, the top-ranked genes selected by statistical cross-analyses were MET, FOS, SNCG, IGFBP4, and BCL2, which were subsequently validated in a larger set of tumor samples (from 17 control patients and 18 TF patients). Confirmation at the protein level by tissue microarray immunohistochemistry was observed for ER$\alpha, \gamma$-synuclein, and insulin-like growth factor binding protein 4 proteins in the 35 original samples. In an independent series of breast tumor samples (19 nonrelapsing and 14 relapsing), reduced expression of ESR1/ER $\alpha$, IGFBP4, SNCG, BCL2, and FOS was observed in the relapsing group and was associated with a shorter overall survival. Low mRNA expression levels of $E S R 1 / E R \alpha, B C L 2$, and FOS were also associated with a shorter relapse-free survival (RFS). Using a Cox multivariate regression analysis, we identified BCL2 and FOS as independent prognostic markers associated with RFS. Finally, the BCL2/FOS signature was demonstrated to have more accurate prognostic value for RFS than $E S R 1 / E R \alpha$ alone (likelihood ratio test).

Conclusions We identified molecular markers including a BCL2/FOS signature associated with tamoxifen failure; these markers may have clinical potential in the management of ERpositive breast cancer.

Cl: confidence interval; ER: estrogen receptor; HR: hazard ratio; IGFBP: insulin-like growth factor binding protein; OS: overall survival; PCR: polymerase chain reaction; RFS: relapse-free survival; RTQ-PCR: real-time quantitative PCR; SNCG: $\gamma$-synuclein; TF: tamoxifen failure; TMA: tissue microarray. 


\section{Introduction}

Breast cancer remains a global public health problem, with some 1.1 million women newly diagnosed with breast cancer in 2002 [1]. Nevertheless, there has been a decline in breast cancer mortality in the Western world over the past decade, which is at least in part attributable to the use of tamoxifen adjuvant therapy $[2,3]$. For estrogen receptor (ER)-positive cancers, 5 years of adjuvant tamoxifen therapy reduces the annual breast cancer death rate by $31 \%$, with a persistent cumulative effect even 15 years after primary treatment [3]. Impressive early data with tamoxifen in the adjuvant setting led clinicians to use tamoxifen as neoadjuvant therapy to avoid surgery in elderly women with ER-positive cancer [4]. However, long-term follow up and clinical trials demonstrated that up to $62 \%$ of cancers initially responsive to endocrine therapy subsequently escaped control, with the patient then requiring salvage surgery $[4,5]$. Thus, the use of tamoxifen as primary endocrine therapy has been reserved for patients who decline or are unfit for surgery as first-line therapy.

Although aromatase inhibitors may replace tamoxifen as firstline neoadjuvant and adjuvant endocrine therapy for most postmenopausal women, tamoxifen will continue to play a role in premenopausal women as a second-line therapy in postmenopausal women and in chemoprevention for all age groups [6]. However, the molecular mechanisms that are involved in the chemoresistance to tamoxifen remain unclear; understanding such processes could benefit clinical decision making.

Recent advances in genomics have provided tools that allow gene expression profiling of solid tumors. Various studies examining gene expression profiles of breast cancer have allowed the molecular classification of clinically distinct subclasses of tumors [7,8] and the identification of molecular markers associated with prognosis/clinical outcome [9-11] and of predictive signatures that relate to therapeutic response $[12,13]$. In this study our aims was to identify a set of candidate molecular markers associated with failure of tamoxifen treatment and that can discriminate between patients with tamoxifen-sensitive breast cancer and those with tamoxifen-resistant breast cancer. These molecular markers could be useful in a clinical setting to plan patient management based on tumor biology. To achieve our objectives, we used a variety of techniques: cDNA arrays to identify a discriminatory gene expression signature, real-time quantitative PCR (RTQ$\mathrm{PCR}$ ) to examine gene expression at the transcript level, and tissue microarrays (TMAs) with immunohistochemistry to look at protein expression levels of the candidate markers in a first cohort of breast tumor samples. An independent cohort of patients from a different geographical location was then used to assess, using RTQ-PCR, the pertinence of the molecular markers identified. This work presents a step toward using molecular markers of tamoxifen failure as tools of clinical utility.

\section{Materials and methods Cohort of patients and breast tumor samples used for biomarker identification}

A first cohort of 35 postmenopausal Caucasian women (age range 41 to 92 years; median age 74 years) with ER- $\alpha$-positive primary breast cancer diagnosed at the Ninewells Hospital (Dundee, UK), for whom complete clinical and pathological data were available, were studied (Table 1). Eighteen women were considered initially unfit for surgery or declined surgical intervention and received neoadjuvant tamoxifen therapy only (20 mg/day). Tumors were monitored by clinical caliper measurement and mammography. After an initial response, as indicated by a clinical and mammographic reduction in tumor size, the tumors increased in size despite tamoxifen therapy and were removed by surgical excision (tamoxifen failure [TF] group; $n=18$ ) and used in the study. No tissue from these patients prior to endocrine therapy was available. Breast tumor samples from the control group (age-matched women selected from the same geographic and ethnic population who underwent surgical resection before any endocrine therapy, and who did not exhibit any cancer recurrence for 5 years after primary surgical resection and subsequent adjuvant treatment with tamoxifen alone) were excised. Using the $\chi^{2}$ test, there was no significant difference in age, histologic grade, lymph node status, or tumor size between the two groups (Table 1). Informed consent was obtained from all patients, and the study was approved by the ethics committee of the institution.

From this cohort, 18 tumor samples (from eight control patients and $10 \mathrm{TF}$ patients), for which sufficient total RNA could be obtained, were used in the initial cDNA array investigation; the whole set (17 control samples and 18 TF samples) was used for RTQ-PCR measurements; and 33 samples were used to conduct the TMA experiments (16 control samples and 17 TF samples; formalin-fixed paraffin-embedded blocks were not available for two patients).

\section{Total RNA extraction}

Surgical resection specimens were transported fresh to the adjacent pathology laboratory, and small pieces of tumor tissue were dissected out by a pathologist and snap frozen in liquid nitrogen before storage at $-80^{\circ} \mathrm{C}$. Approximately $10 \mathrm{mg}$ tissue was homogenized in $750 \mu \mathrm{l}$ QIAzol lysis reagent (Qiagen Ltd, Crawley, West Sussex, UK). RNA quality was assured using the BioAnalyzer $2100^{\mathrm{TM}}$ (Agilent Technologies, Palo Alto, CA, USA).

\section{Transcriptome study by cDNA-array technology}

Eighteen tumor samples (from eight control patients and $10 \mathrm{TF}$ patients) were used in cDNA array analysis (screening set). Gene expression levels were determined using large-scale measurement experiments using customized nylon cDNA arrays $\left(7.5 \times 11.5 \mathrm{~cm} ; 1,034\right.$ human genes; 12 genes $\left./ \mathrm{cm}^{2}\right)$ produced in our facility (TAGC Laboratory, University of AixMarseille II, France), as previously described [14-16]. Follow- 
Table 1

\begin{tabular}{|c|c|c|c|}
\hline Characteristic & Control group $(n=17)$ & TF group $(n=18)$ & $\mathrm{Pa}$ \\
\hline \multicolumn{4}{|l|}{ Age (years) } \\
\hline$<70$ & 5 & 4 & NS (0.92) \\
\hline$\geq 70$ & 12 & 14 & \\
\hline \multicolumn{4}{|l|}{ Histological grade } \\
\hline$I+\|$ & 14 & 8 & NS $(0.11)$ \\
\hline III & 3 & 8 & \\
\hline \multicolumn{4}{|l|}{ Lymph node status } \\
\hline Node negative & 10 & 4 & NS (0.06) \\
\hline Node positive & 7 & 14 & \\
\hline \multicolumn{4}{|c|}{ Macroscopic tumor size } \\
\hline$<30 \mathrm{~mm}$ & 11 & 6 & NS (0.17) \\
\hline$\geq 30 \mathrm{~mm}$ & 6 & 11 & \\
\hline
\end{tabular}

a $P$-value $\left(\chi^{2}\right.$ test) was considered significant when $P<0.05$. bInformation available for 33 patients. clnformation available for 34 patients. ER, estrogen receptor; NS, not significant; TF, tamoxifen failure.

ing hybridization to each array with a ${ }^{33} \mathrm{P}$-labeled probe synthesized by reverse transcribing $5 \mu \mathrm{g}$ total RNA [14], hybridization signals were scanned with a FUJ BAS 5000 beta imager (Raytest, Asnieres, France) and then quantified with the BZScan software, in accordance with the developers' recommendations [17] (TAGC Laboratory, Marseille, France). Intensity values were then adjusted using a normalization step based on the DNA quantification of each spot and the sum of intensities detected in each experiment.

We conducted supervised analyses of genes that could allow discrimination between the two classes of tumor samples (control and TF) by cross-analyzing the results given by three independent methods: supervised analysis using a signal-tonoise metric [18]; significance analysis of microarrays [19]; and Mann-Whitney test $(P<0.05)$. For each method, we considered the ranks assigned for each gene, and we selected the genes with the best sum of the ranks obtained using the three methods. Expression profiles were then analyzed by hierarchical clustering using the Cluster program developed by Eisen and colleagues [20], and the results visualized using Treeview software (Eisen Laboratory, Berkeley, CA, USA).

\section{Real-time quantitative PCR analysis}

Using RTQ-PCR, tumor samples were examined as previously described [15], using a LightCycler ${ }^{\circledR} 1.5$ (Roche, Meylan, France) in combination with the LightCycler Faststart DNA Master Sybr Green I (Roche), in accordance to the manufacturer's recommendations. For each gene, the amount of target was calculated as follows by normalization to the expression of the $28 S$ gene and relative to the calibrator: $E^{-}\left(\Delta \mathrm{C}\right.$ Tsample- $\Delta \mathrm{C}_{\text {Tcali- }}$ brator), where $\mathrm{E}$ is the efficiency of the RTQ-PCR reaction calculated with the slope of the corresponding standard curve, $\mathrm{C}_{\mathrm{T}}$ is the threshold cycle, and $\Delta \mathrm{C}_{\mathrm{T}}$ is $\left(\mathrm{C}_{\mathrm{T}}\right.$ target gene $-\mathrm{C}_{\mathrm{T}}$ 28S). Statistical analysis of RTQ-PCR measurements was performed using the Mann-Whitney test and the Spearman's rank test, by Statgraphics ${ }^{\circledR} 3$ plus software (Statgraphics Centurion, Herndon, VA, USA). The results were judged to be statistically significant at a confidence level greater than $95 \%(P$ $<0.05)$.

\section{Tissue microarray experiments}

Thirty-three tumor samples (16 control and 17 TF) were used to construct a TMA, containing up to six $0.6 \mathrm{~mm}$ diameter cores from each invasive breast tumor using a manual tissue arrayer (Beecher Instruments Inc., Sun Prairie, WI, USA). Briefly, hemotoxylin and eosin stained tumor sections were reviewed by a single pathologist (KER), and areas suitable for inclusion in the TMA marked. Sections were matched to their corresponding wax blocks (the donor blocks), and $0.6 \mathrm{~mm}$ diameter cores of tumor were removed from these donor blocks and inserted into the recipient paraffin TMA block in a grid arrangement.

Four micrometer sections were cut from the TMA block and placed onto poly-L-lysine coated glass slides (VWR International Ltd., Lutterworth, UK) and dried for 1 hour at $60^{\circ} \mathrm{C}$, before being de-paraffinized in Histoclear (National Diagnostics, Hessle, UK) and rehydrated through a graded alcohol series. Citric acid buffer (10 mmol/l, $\mathrm{pH} \mathrm{6.0)} \mathrm{was} \mathrm{used} \mathrm{as} \mathrm{a}$ standard microwave-based antigen retrieval method. Sections were microwaved in a microwave compatible pressure vessel 
for 15 minutes before being immunostained on a Dako Autostainer Universal Staining System (Dako, Ely, UK) using Vectastain ${ }^{\circledR}$ ABC kits (Vector Labs, Peterborough, UK), in accordance with the manufacturer's protocol. Briefly, sections were blocked by either normal goat or horse serum containing $10 \%$ (vol/vol) from stock avidin solution (Vector Labs) for 20 minutes followed by incubation with primary antibody, including 10\% (vol/vol) from stock biotin solution (Vector Labs) for 1 hour to reduce nonspecific background staining. The following anti-human antibodies were used as primary antibodies: antiinsulin-like growth factor binding protein 4 (anti-IGFBP4; ab4252); anti-c-Fos (ab7963); anti- $\gamma$-synuclein (anti-SNCG; ab6169; Abcam Ltd, Cambridge, UK); anti-Bcl2 (clone 124; Dako); anti-ER- $\alpha$ clone 6F11 (Vision BioSystems, Newcastleupon-Tyne, UK); and anti-c-Met (CVD13; Zymed ${ }^{\circledR}$ Laboratories Inc., Paisley, UK). Sections were then incubated with either biotinylated anti-rabbit or anti-mouse antibody for 30 minutes followed by Vectastain ${ }^{\circledR}$ Elite $A B C$ reagent for another 30 minutes. Liquid diaminobenzidine (Dako) was used as a chromogenic agent for 5 minutes and sections were counterstained with Mayer's hematoxylin. In between each immunostaining step, slides were washed briefly in Tris-buffered saline ( $\mathrm{pH}$ 7.6). Sections known to stain positively were included in each batch, and negative controls were prepared by replacing the primary antibody with Tris-buffered saline.

TMA scoring was carried out independently by one of the authors (KER, SMH), and concordance was confirmed by a specialist breast pathologist (CAP) using a Nikon Eclipse E600 light microscope. Antibody staining of cores containing tumor were assessed using a scoring system based on the quickscore method [21]. Briefly, the proportion of positive cells was estimated and given a score on a scale from 1 to 6 ( $1=0 \%$ to $4 \% ; 2=5 \%$ to $19 \% ; 3=20 \%$ to $39 \% ; 4=40 \%$ to $59 \% ; 5=60 \%$ to $79 \%$; and $6=80 \%$ to $100 \%$ ). The average intensity of the positively staining cells was estimated and given a score from 0 to 3 ( $0=$ no staining; $1=$ weak staining; 2 = intermediate staining; and $3=$ strong staining). A quickscore was then calculated by multiplying the percentage of cells staining score by the intensity score, to yield a minimum value of 0 and a maximum value of 18 .

\section{Independent cohort of breast tumor samples of tamoxifen failure}

A separate cohort of 33 Caucasian women (age range 31 to 77 years; median age 55.5 years) with ER-positive primary breast cancer diagnosed at Centre Léon Bérard (Lyon, France) were selected (Table 2) and provided by the Centre de Ressources Biologiques of the Centre Léon Bérard (Lyon, France). The breast tumor samples were excised from women who did not receive endocrine therapy, chemotherapy, or radiotherapy before surgery. Complete clinical, histologic, and biologic information was available. All patients received postoperative adjuvant endocrine therapy alone for 5 years (tamoxifen $20 \mathrm{mg} /$ day) and no chemotherapy. Fourteen patients relapsed under tamoxifen treatment (relapsing group) and 19 patients did not have a recurrence after 5 years of tamoxifen treatment (nonrelapsing group). Informed consent was obtained from all patients. Using the $\chi^{2}$ test, there were no significant differences between groups in age, histologic grade, lymph node status, or tumor size (Table 2).

RNA extraction was performed as described above. RTQPCR experiments were conducted using a LightCycler $480^{\circledR}$

Table 2

\begin{tabular}{|c|c|c|c|}
\hline Characteristic & Control group $(n=19)$ & TF group $(n=14)$ & $\mathrm{Pa}$ \\
\hline \multicolumn{4}{|l|}{ Age (years) } \\
\hline$<70$ & 16 & 8 & NS (0.18) \\
\hline$\geq 70$ & 3 & 6 & \\
\hline \multicolumn{4}{|l|}{ Histological grade } \\
\hline$I+I I$ & 12 & 8 & NS (1) \\
\hline III & 7 & 6 & \\
\hline \multicolumn{4}{|l|}{ Lymph node status } \\
\hline Node negative & 0 & 0 & NS (1) \\
\hline Node positive & 19 & 14 & \\
\hline \multicolumn{4}{|c|}{ Macroscopic tumor size } \\
\hline$<30 \mathrm{~mm}$ & 10 & 9 & NS (0.75) \\
\hline$\geq 30 \mathrm{~mm}$ & 9 & 5 & \\
\hline
\end{tabular}

a $P$ value $\left(\chi^{2}\right.$ test) was considered significant when $P<0.05$. ER, estrogen receptor; NS, not significant; TF, tamoxifen failure. 
(Roche) in combination with the LC480 SybrGreen I Master Mix (Roche), in accordance with the manufacturer's recommendations. The expression of the six genes was investigated using the same pair of primers, and the same calculation and normalization methods as described above. Statistical analysis of RTQ-PCR measurements was performed using the MannWhitney test using the Statgraphics ${ }^{\circledR} 3$ plus software (Statgraphics Centurion). The results were judged statistically significant at a confidence level greater than $95 \%(P<0.05)$.

For each gene, the 33 ER-positive breast tumors were then divided into two groups: one of 16 tumors with 'low' mRNA level (lower than the median of the mRNA levels of the 33 breast tumor samples) and another of 17 tumors with 'high' mRNA level (higher than the median of the mRNA levels of the 33 breast tumor samples). Outcomes of interest were overall survival (OS) and relapse-free survival (RFS). OS was measured from the date of diagnosis to death or censored at the last follow up. RFS was measured from the date of diagnosis to relapse or censored at the last follow-up. Survival distributions were estimated using the Kaplan-Meier method and the significance of differences between survival rates was ascertained by the log-rank test, using the SPSS ${ }^{\circledR}$ Software (SPSS Inc., Chicago, IL, USA). Candidate prognostic factors for RFS with a 0.05 significance level in univariate analysis were entered in a multivariate Cox model, and a backward selection procedure was used to build the final model [22]. Likelihood ratio test was used to select the best fit between models [23].

\section{General considerations in statistical analyses}

Because this study is an exploratory analysis, all of the statistical analyses performed in this work were done at the 0.05 significance level, and no correction was applied for multiple testing.

\section{Results \\ Identification of a discriminating 47-gene signature associated with tamoxifen failure}

cDNA arrays were used to identify candidate genes associated with tamoxifen failure. From a training set of 18 tumor samples (eight control and $10 \mathrm{TF}$ ), total RNA was extracted from each sample and used to synthesize the corresponding complex probe to be hybridized on the cDNA arrays. With the aim being to identify a molecular signature that might allow discrimination between the two classes of tumor samples (control and TF), a cross-analysis based on three different statistical methods (significance analysis of microarrays, signal-to-noise statistic method, and Mann-Whitney test) was applied to the normalized cDNA array data. For each method, the ranks assigned to each gene were considered, and the genes selected with the best sum of the ranks obtained using the three methods. Forty-nine discriminant genes arose, and hierarchical clustering of the gene expression profiles discriminated between the two groups of patients (control and TF; Figure 1). Two out of the 49 discriminating genes (HLA-DRA and STAT1) were selected by two individual spots located at different places on the array, emphasizing the reproducibility of the gene signature identified.

Functional annotation of the 47 genes in the signature showed that $34 \%$ of the genes were involved in immune response (B2M, CCL2, CCL3, CD22, CD33, CXCL12, HLA-A, HLADPB1, HLA-DRA, IL1ORA, IL16, IL2RG, IL6, ILF2, TCRA, and TNFRSF7), 23\% in transcription regulation (ELF1, ESR1/ ER $\alpha, F O S, J U N$, JUNB, MAZ, NFYA, PBX1, RXRA, STAT1, and ZNF607), 23\% in cellular proliferation regulation and mitosis control (DLEU2, IGFBP4, MAP2K2, MET, NF1, NOTCH4, PAK1, SNCG, SSSCA1, TEK, and TGFBR2), 9\% in tumor invasion (AMFR, FLT1, MMP13, and MMP16), $4 \%$ in apoptosis (BCL2 and $F A S), 4 \%$ in cell adhesion (CD34 and $R D X)$, and $3 \%$ in other functions. Sixteen genes encoded proteins of the immune system: major histocompatibility complex proteins (B2M, HLA-A, HLA-DPB1, HLA-DRA, and TCRA), cell antigen (CD22 and CD33), receptors (IL2RG, IL10RA, and TNFRSF7), cytokines and chemokines (IL6, IL16, CCL2, CCL3, and CXCL12), and a transcription factor (ILF2). In addition, three of the $23 \%$ of genes involved in transcription regulation were genes that take part in the activator protein-1 transcription complex (FOS, JUN, and JUNB). Interestingly, expression of 17 genes from the 47-gene signature selected in our study (Figure 1 [red asterisks]) was associated with estrogen action, because their expression was modulated by estradiol treatment in breast cancer cells in vitro [15,24-31]. This suggests that identification of estradiol-regulated genes [32] or tamoxifen-regulated genes [33] in vitro might be a good approach to selecting prognostic or predictive molecular markers of ER-positive breast cancer [32-34].

\section{Real-time quantitative PCR investigation of the six top- ranked genes: ESR1/ER $\alpha$, MET, FOS, SNCG, IGFBP4, and $B C L 2$}

Considering the rank assigned to each gene following the statistical cross-analysis performed on the cDNA array data (as described in the Materials and methods section [above]), $E S R 1 / E R \alpha$ emerged as the most discriminating gene, as expected [35-38]. We then investigated the expression of $E S R 1 / E R \alpha$ and that of the five following top-ranked genes (MET, FOS, SNCG, IGFBP4, and BCL2) by RTQ-PCR on the initial set of 18 tumor samples (eight control and $10 \mathrm{TF}$ ). Using Spearman rank correlation, for five genes (ESR1/ER $\alpha$, FOS, IGFBP4, MET, and SNCG) the data demonstrated a positive and significant $(P<0.05)$ correlation between mRNA levels measured by cDNA array and RTQ-PCR, indicating consistency between the cDNA array and the RTQ-PCR measurements (Table 3).

To explore the reliability of the expression signature previously identified by cDNA array, RTQ-PCR of ESR1/ER $\alpha$, FOS, IGFBP4, MET, BCL2, and SNCG gene expression was examined in a larger set of 35 tumor samples (17 control and 18 


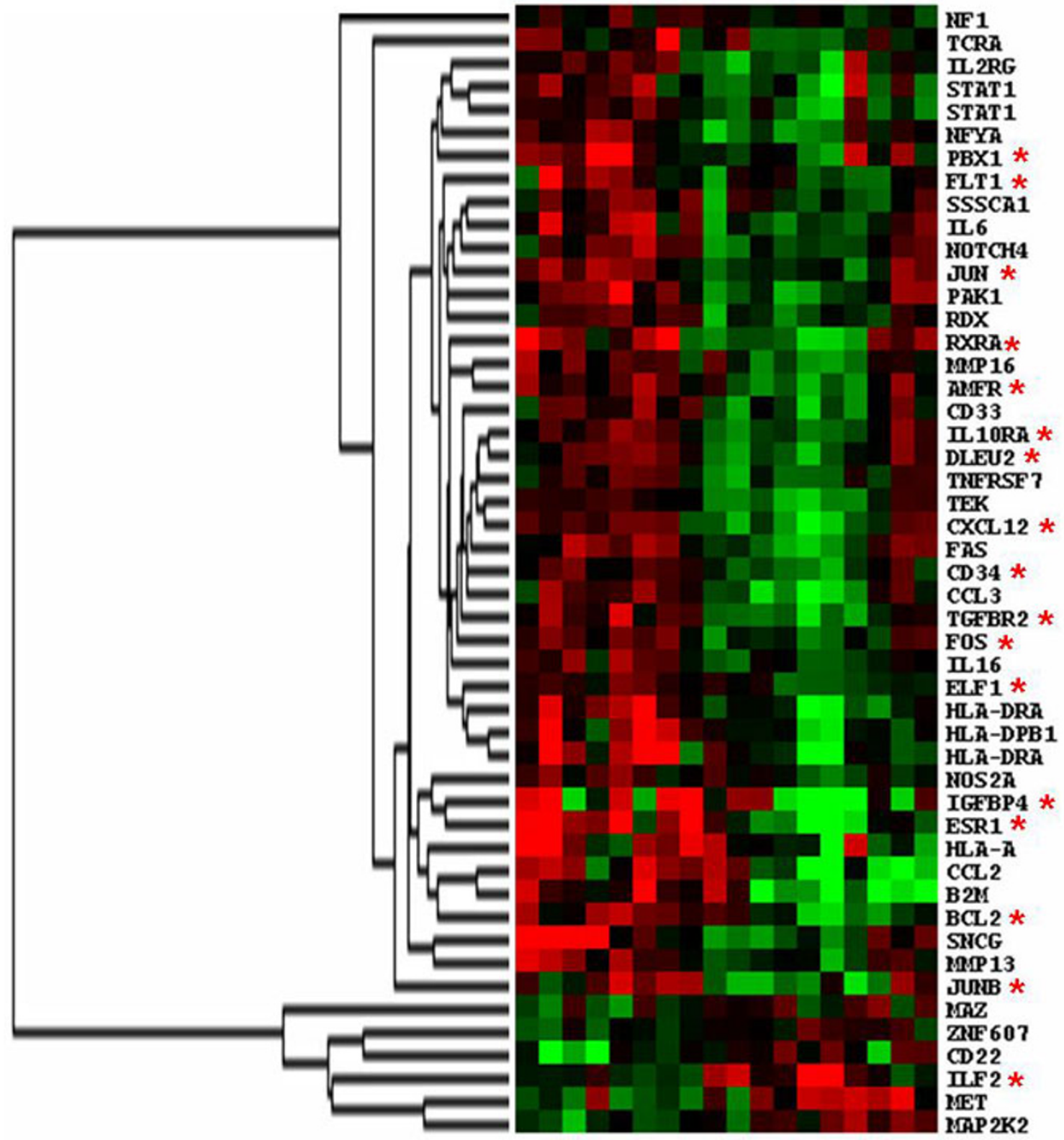

Dendogram of 18 tumor samples (eight control and 10 TF). Using the Cluster and Treeview software packages, the samples were ordered according to their degree of similarity after hierarchical clustering of the expression profiles of the 49 selected genes. Each column represents a tumor sample and each row a single gene. Expression levels above the median are presented in red and expression levels below the median are presented in green. The control tumor samples are colored blue, and the TF tumor samples yellow. Red asterisks represented genes whose expression is regulated by estradiol treatment in breast cancer cell lines [15,24-31]. C, control; TF, tamoxifen failure. 
Table 3

\begin{tabular}{lll}
\hline $\begin{array}{l}\text { Spearman rank correlation between the cDNA-array and the } \\
\text { RTQ-PCR measurements }\end{array}$ \\
\hline
\end{tabular}

aSpearman rank correlation coefficient. $\mathrm{b} P$ value (Spearman rank correlation test) was considered significant when $P<0.05$. NS, not significant.

TF), including the 18 samples used in the initial screen. The data presented in Table 4 demonstrate a significant difference of expression between the control and TF groups for the six genes (Mann-Whitney test). As expected, ESR1/ER $\alpha$ emerged as the most significant gene $\left(P<10^{-6}\right)$. mRNA levels of four genes (IGFBP4, SNCG, BCL2, and FOS) were significantly lower in the TF groups, whereas MET mRNA levels were significantly higher in the TF group.
Using the Mann-Whitney test, the expression of the six genes was compared with clinical and pathological parameters Table 1). ESR1/ER $\alpha(P=0.002)$ and $B C L 2(P=0.003)$ genes had significantly higher expression in axillary node metastasis-negative patients $(n=14)$ than in node-positive patients $(n=21)$. Moreover, gene expression levels of ESR1/ER $\alpha(P=0.004)$, $B C L 2(P=0.003)$, and FOS $(P=0.01)$ were significantly lower in grade III $(n=11)$ than in grade I + II $(n=22)$ tumor samples. Finally, MET mRNA levels were significantly increased $(P=0.016)$ in tumor grade III samples compared with grade I + II samples.

\section{Immunohistochemical examination of ER- $\alpha$, C-Fos, IGFBP4, c-Met, SNCG, and Bcl2 on tissue microarray}

In order to explore, at the protein level, the expression variations of the six top-ranked genes and to ascertain whether immunohistochemical detection of these proteins on tissue sections could differentiate between the control and the TF groups, immunohistochemistry was performed on TMAs containing cores of tissue from 33 out of the 35 patients (16 control and $17 \mathrm{TF} ;$ Figure 2). For two samples (one control and one TF), tumor sections were not available. A Spearman rank correlation test between the TMA data and the RTQ-PCR measurements revealed a significant and positive correlation for ESR1/ER- $\alpha\left(P<10^{-4}\right), \mathrm{Bcl} 2(P=0.003)$, and IGFBP4 $(P$ $=0.05$; data not shown). The association of protein immunohistochemical detection with the control or TF group was studied using the Fisher exact test (Table 5). There was a significant statistical association between ER- $\alpha(P=0.0004)$,

Table 4

Statistical comparison of the mRNA levels measured by RTQ-PCR between the control and TF groups of tumor samples (Ninewells Hospital, Dundee, UK)

\begin{tabular}{|c|c|c|c|c|c|}
\hline \multirow[t]{2}{*}{ Genes } & \multirow[t]{2}{*}{ Tumor samples } & \multirow[t]{2}{*}{ Number of samples } & \multicolumn{3}{|c|}{ mRNA levels (arbitrary units) } \\
\hline & & & Median & Range & $P a$ \\
\hline \multirow[t]{2}{*}{ ESR1 } & Control & 17 & 72.71 & 28.14 to 261.30 & $<10^{-6}$ \\
\hline & TF & 18 & 1.98 & 0.13 to 20.85 & \\
\hline \multirow[t]{2}{*}{ IGFBP4 } & Control & 17 & 2.53 & 1.44 to 5.93 & 0.0004 \\
\hline & TF & 18 & 1.12 & 0.15 to 3.24 & \\
\hline \multirow[t]{2}{*}{ MET } & Control & 17 & 0.48 & 0.15 to 2.46 & 0.009 \\
\hline & TF & 18 & 1.23 & 0.18 to 12.51 & \\
\hline \multirow[t]{2}{*}{ FOS } & Control & 17 & 0.36 & 0.04 to 2.54 & 0.02 \\
\hline & TF & 18 & 0.15 & 0.02 to 1.46 & \\
\hline \multirow[t]{2}{*}{ SNCG } & Control & 17 & 0.78 & 0.08 to 34.01 & 0.036 \\
\hline & TF & 18 & 0.31 & 0.05 to 4.39 & \\
\hline \multirow[t]{2}{*}{$B C L 2$} & Control & 17 & 2.87 & 0.08 to 7.14 & 0.04 \\
\hline & TF & 18 & 1.08 & 0.13 to 6.8 & \\
\hline
\end{tabular}

a $P$ value (Mann-Whitney test) was considered significant when $P<0.05$. TF, tamoxifen failure. 
Table 5 Statistical comparison of protein expression measured by TMA
between the control and TF groups of tumor samples $(n=33$;
Ninewells Hospital, Dundee, UK)

\begin{tabular}{|c|c|c|c|c|}
\hline \multirow[t]{2}{*}{ Proteins } & \multirow[t]{2}{*}{ Quickscore } & \multicolumn{2}{|c|}{ Samples ( $n[\%]$ ) } & \multirow[t]{2}{*}{$\mathrm{Pa}$} \\
\hline & & Control & TF & \\
\hline \multirow[t]{4}{*}{ ER- $\alpha$} & 0 and $<4$ & $1(6)$ & $11(65)$ & 0.0004 \\
\hline & From 4 to $<8$ & $4(25)$ & $4(24)$ & \\
\hline & From 8 to $<12$ & $5(31)$ & $2(12)$ & \\
\hline & From 12 to 18 & $6(38)$ & $0(0)$ & \\
\hline \multirow[t]{4}{*}{ SNCG } & 0 and $<4$ & $0(0)$ & $0(0)$ & 0.02 \\
\hline & From 4 to $<8$ & $6(38)$ & $7(41)$ & \\
\hline & From 8 to $<12$ & $1(6)$ & $7(41)$ & \\
\hline & From 12 to 18 & $9(56)$ & $3(18)$ & \\
\hline \multirow[t]{4}{*}{ IGFBP4 } & 0 and $<4$ & $5(31)$ & $8(47)$ & 0.03 \\
\hline & From 4 to $<8$ & $4(25)$ & $5(29)$ & \\
\hline & From 8 to $<12$ & $1(6)$ & $4(24)$ & \\
\hline & From 12 to 18 & $6(38)$ & $0(0)$ & \\
\hline \multirow[t]{4}{*}{ c-Fos } & 0 and $<4$ & $1(6)$ & $0(0)$ & NS (0.08) \\
\hline & From 4 to $<8$ & $7(44)$ & $2(12)$ & \\
\hline & From 8 to $<12$ & $1(6)$ & $2(12)$ & \\
\hline & From 12 to 18 & $7(44)$ & $13(76)$ & \\
\hline \multirow[t]{4}{*}{ c-Met } & 0 and $<4$ & $1(6)$ & $0(0)$ & NS (0.29) \\
\hline & From 4 to $<8$ & $1(6)$ & $4(24)$ & \\
\hline & From 8 to $<12$ & $6(38)$ & $8(47)$ & \\
\hline & From 12 to 18 & $8(50)$ & $5(29)$ & \\
\hline \multirow[t]{4}{*}{$\mathrm{Bcl} 2$} & 0 and $<4$ & $5(31)$ & $7(41)$ & NS (0.78) \\
\hline & From 4 to $<8$ & $4(25)$ & $2(12)$ & \\
\hline & From 8 to $<12$ & $1(6)$ & $2(12)$ & \\
\hline & From 12 to 18 & $6(38)$ & $6(35)$ & \\
\hline
\end{tabular}

a $P$ value (Fisher exact test) was considered significant when $P<$ 0.05 . ER, estrogen receptor; IGFBP, insulin-like growth factor binding protein; NS, not significant; SNCG, $\gamma$-synuclein; TF, tamoxifen failure; TMA, tissue microarray.

SNCG $(P=0.02)$, and IGFBP4 $(P=0.03)$ immunohistochemical staining with patient group (control or TF). No significant association was observed for $\mathrm{c}-\mathrm{Fos}, \mathrm{c}-\mathrm{Met}$, and $\mathrm{Bcl} 2$ protein detection $(P>0.05)$

Real-time quantitative PCR investigation of ESR1/ER $\alpha$, MET, FOS, SNCG, IGFBP4, and BCL2 in an independent cohort of breast tumor samples

We examined an independent cohort of ER-positive breast cancer patients from a different geographic location (Centre
Léon Bérard, Lyon, France) to assess the pertinence of the biomarkers identified in the study. The separate cohort ( $n=$ 33) included 14 patients who relapsed under tamoxifen treatment (relapsing group) and 19 patients who did not relapse after 5 years of tamoxifen treatment (nonrelapsing group). In this cohort, low mRNA levels of FOS, BCL2, SNCG, and IGFBP4 were significantly associated with tamoxifen failure ( $P$ $<0.05$, Mann-Whitney test; Table 6). MET was the only biomarker that could not be confirmed.

\section{Prognosis significance of the biomarkers identified}

We then used univariate analysis (log-rank test) to study further the prognostic value of the biomarkers identified. Apart from (as expected) ESR1/ER $\alpha\left(P<10^{-4}\right)$, univariate analysis revealed that low expression mRNA levels of FOS $\left(P<10^{-4}\right)$, BCL2 $\left(P<10^{-4}\right)$, SNCG $(P=0.008)$, and IGFBP4 $(P=$ 0.038 ) were significantly associated with shorter OS (Figure 3 and Table 7). Low expression mRNA levels of ESR1/ER $\alpha$, $B C L 2$, and FOS were also significantly associated with shorter RFS ( $P<10^{-4}$; Figure 4 and Table 8), whereas low expression of SNCG and IGFBP4 was close to statistical significance $(P=0.078$ and $P=0.083$, respectively; Figure 4). No significant association between MET mRNA level and OS $(P=0.879)$ or RFS $(P=0.449)$ could be identified. In Cox multivariate regression analysis of $\mathrm{OS}$, only the prognostic significance of $E S R 1 / E R \alpha(P=0.032$; hazard ratio $[\mathrm{HR}]=0.17$, $95 \%$ confidence interval $[\mathrm{Cl}]=0.03$ to 0.86$)$ and FOS $(P=$ $0.049 ; \mathrm{HR}=0.22,95 \% \mathrm{Cl}=0.06$ to 1.00 ) persisted (Table 7). Cox multivariate regression analysis of RFS revealed that $B C L 2\left(P<10^{-4} ; \mathrm{HR}=0.10,95 \% \mathrm{Cl}=0.03\right.$ to 0.34$)$ and $F O S$ $(P=0.038 ; \mathrm{HR}=0.15,95 \% \mathrm{Cl}=0.03$ to 0.89$)$ were independent prognostic markers and that patients with low mRNA levels of BCL2 or FOS were at greater risk for relapse (Table 8).

We then defined a two-gene signature based on BCL2 and FOS mRNA expression levels. This signature was constructed by selecting patients who expressed low mRNA levels of both $B C L 2$ and FOS (group $A ; n=14$ ) versus patients exhibiting high expression levels of at least one of these two genes (group $\mathrm{B} ; n=19$ ). Among these 19 patients, concomitant high levels of both BCL2 and FOS were detected in 15 samples. Concerning the four patients with high expression levels of either BCL2 or FOS, the Kaplan-Meier curve for RFS could be superimposed over those of the patients having high levels of both BCL2 and FOS. The resulting Kaplan-Meier curves for RFS according to the BCL2/FOS signature are illustrated in Figure 5 (univariate analysis, $P<10^{-4}$; $\mathrm{HR}=0.014,95 \% \mathrm{Cl}=$ 0.002 to 0.117$)$.

Finally, we tested the BCL2/FOS signature with respect to RFS to determine which final model is better. The model with the BCL2/FOS signature was better fitting (likelihood = 90.35) than the model with ESR1/ER $\alpha$ alone (likelihood = $109.28 ; P<10^{-4}$ ) or with only BCL2 (likelihood $=102.64 ; P$ 


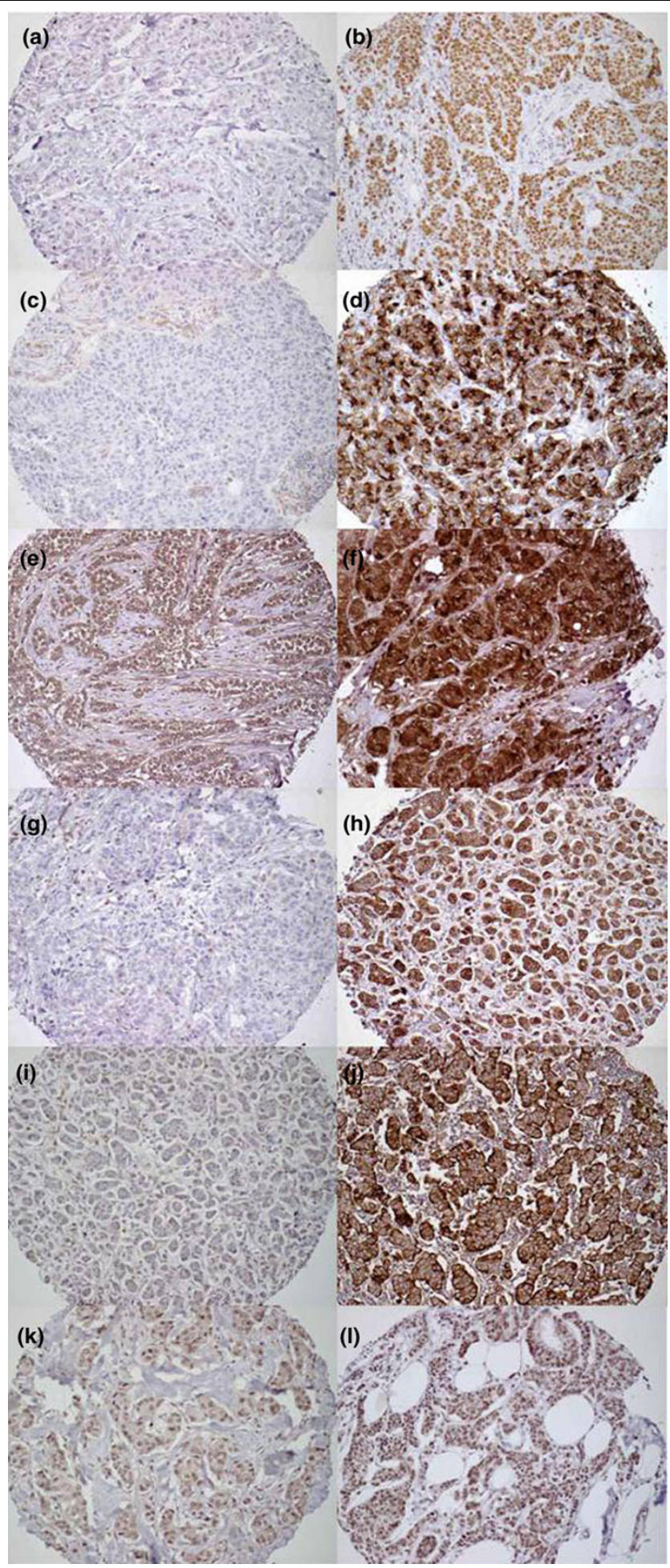

Example cores of breast tumors from the TMA. Presented are example cores of breast tumors from the TMA showing immunohistochemical staining for (a, b) ER- $\alpha,(\mathbf{c}, \mathbf{d})$ IGFBP4, (e, f) SNCG, (g, h) Bcl2, (i, j) c-Met, and (k, l) c-Fos. Panel a shows weak staining for ER- $\alpha$, b strong positive staining for ER- $\alpha, c$ negative staining for IGFBP4, $d$ strong staining for IGFBP4, e weak positive staining for SNCG, $f$ strong positive staining for SNCG, $g$ negative staining for $\mathrm{Bcl} 2, \mathrm{~h}$ strong positive staining for $\mathrm{Bcl} 2$, i negative staining for $\mathrm{c}-\mathrm{Met}$, $\mathrm{j}$ strong positive staining for $\mathrm{c}-$ Met, $\mathrm{k}$ negative staining for c-Fos, and I strong positive staining for c-Fos. All images were taken at $\times 40$ objective. ER, estrogen receptor; IGFBP, insulin-like growth factor binding protein; SNCG, $\gamma$-synuclein; TMA, tissue microarray. 
Table 6

Statistical comparison of the mRNA levels measured by RTQ-PCR between the nonrelapsing and relapsing groups of tumor samples from the independent cohort (Centre Léon Bérard, Lyon, France)

\begin{tabular}{|c|c|c|c|c|c|}
\hline \multirow[t]{2}{*}{ Genes } & \multirow[t]{2}{*}{ Tumor samples } & \multirow[t]{2}{*}{ Number of samples } & \multicolumn{3}{|c|}{ mRNA levels (arbitrary units) } \\
\hline & & & Median & Range & $\mathrm{Pa}$ \\
\hline \multirow[t]{2}{*}{ ESR1 } & Nonrelapsing & 19 & 117.9 & 0.33 to 472.35 & 0.0001 \\
\hline & Relapsing & 14 & 2.55 & 0.03 to 51.75 & \\
\hline \multirow[t]{2}{*}{ IGFBP4 } & Nonrelapsing & 19 & 97.52 & 0.02 to 12691.41 & 0.02 \\
\hline & Relapsing & 14 & 1.40 & 0.01 to 7282.33 & \\
\hline \multirow[t]{2}{*}{ MET } & Nonrelapsing & 19 & 0.10 & 0.08 to 10.26 & NS (0.33) \\
\hline & Relapsing & 14 & 0.12 & 0.10 to 2.28 & \\
\hline \multirow[t]{2}{*}{ FOS } & Nonrelapsing & 19 & 8.72 & 0.03 to 47.92 & 0.0001 \\
\hline & Relapsing & 14 & 0.28 & 0.01 to 1.46 & \\
\hline \multirow[t]{2}{*}{ SNCG } & Nonrelapsing & 19 & 5.99 & 0.04 to 915.74 & 0.005 \\
\hline & Relapsing & 14 & 0.52 & 0.01 to 18.28 & \\
\hline \multirow[t]{2}{*}{$B C L 2$} & Nonrelapsing & 19 & 5.59 & 0.01 to 17.24 & 0.0004 \\
\hline & Relapsing & 14 & 0.12 & 0.01 to 8.57 & \\
\hline
\end{tabular}

a $P$ value (Mann-Whitney test) was considered significant when $P<0.05$. NS, not significant; RTQ-PCR, real-time quantitative PCR.

$=0.0005$ ) or FOS (likelihood $=114.47 ; P<10^{-4}$ ), demonstrating that our two-gene signature has a better prognostic value than $E S R 1 / E R \alpha$ alone for RFS. We then tested the model with both BCL2/FOS and ESR1/ER $\alpha$ and found that the combination was better fitting (likelihood $=89.82$ ) than the model with $E S R 1 / E R \alpha$ alone (likelihood $=109.28 ; P<10^{-4}$ ), demonstrating that the BCL2/FOS signature could improve the prognostic value of $E S R 1 / E R \alpha$ for RFS.

\section{Discussion}

ER immunohistochemistry is a widely available but imperfect test for guiding likely clinical response to tamoxifen treatment. Using clinical material from women with ER-positive breast cancers treated with tamoxifen alone, this study sought biologic markers associated with tamoxifen failure in breast cancer. Transcriptome data identified a specific 47-gene signature associated with tamoxifen failure.

A key issue in gene expression profiling studies is the difficulty in finding overlapped gene expression profiles in independent

Table 7

Univariate and multivariate analysis of the six genes in relation to OS among the $\mathbf{3 3}$ breast cancer samples from the independent cohort (Centre Léon Bérard, Lyon, France)

\begin{tabular}{|c|c|c|c|c|c|c|}
\hline \multirow[t]{2}{*}{ Genes } & \multicolumn{3}{|c|}{ Univariate $(n=33)$} & \multicolumn{3}{|c|}{ Multivariate $(n=33)$} \\
\hline & HR & $95 \% \mathrm{Cl}$ & $P a$ & HR & $95 \% \mathrm{Cl}$ & $P a$ \\
\hline ESR1 & 0.09 & 0.02 to 0.38 & $<10^{-4}$ & 0.17 & 0.03 to 0.86 & 0.032 \\
\hline FOS & 0.12 & 0.03 to 0.42 & $<10^{-4}$ & 0.22 & 0.06 to 1.00 & 0.049 \\
\hline$B C L 2$ & 0.07 & 0.01 to 0.31 & $<10^{-4}$ & & & $\mathrm{NS}(2)^{\mathrm{b}}$ \\
\hline SNCG & 0.24 & 0.08 to 0.75 & 0.008 & & & NS(3) \\
\hline IGFBP4 & 0.34 & 0.12 to 0.98 & 0.038 & & & $N S(1)$ \\
\hline$M E T$ & 1.08 & 0.40 to 2.88 & NS & $N^{c}$ & ND & ND \\
\hline
\end{tabular}

a $P$ value was considered significant when $P<0.05$. bNS(i), order in which the variable was deleted from the model. cND indicates 'not done'; multivariate analysis was done using the variables found to be significant in univariate analysis. $\mathrm{Cl}$, confidence interval; HR, hazard ratio; NS, not significant; OS, overall survival. 
Table 8

Univariate and multivariate analysis of the six genes in relation to RFS among the 33 breast cancer samples from the independent cohort (Centre Léon Bérard, Lyon, France)

\begin{tabular}{|c|c|c|c|c|c|c|}
\hline \multirow[t]{2}{*}{ Genes } & \multicolumn{3}{|c|}{ Univariate $(n=33)$} & \multicolumn{3}{|c|}{ Multivariate $(n=33)$} \\
\hline & $\mathrm{HR}$ & $95 \% \mathrm{Cl}$ & $P a$ & $\mathrm{HR}$ & $95 \% \mathrm{Cl}$ & $P a$ \\
\hline ESR1 & 0.12 & 0.04 to 0.36 & $<10^{-4}$ & & & NS \\
\hline FOS & 0.20 & 0.08 to 0.51 & $<10^{-4}$ & 0.15 & 0.03 to 0.89 & 0.038 \\
\hline$B C L 2$ & 0.08 & 0.02 to 0.24 & $<10^{-4}$ & 0.10 & 0.03 to 0.34 & $<10^{-4}$ \\
\hline SNCG & 0.46 & 0.19 to 1.11 & NS & $N D^{b}$ & ND & ND \\
\hline IGFBP4 & 0.46 & 0.19 to 1.12 & NS & ND & ND & ND \\
\hline MET & 1.38 & 0.60 to 3.21 & NS & ND & ND & ND \\
\hline
\end{tabular}

a $P$ value was considered significant when $P<0.05$. bND indicates 'not done'; multivariate analysis was done using the variables found to be significant in univariate analysis. $\mathrm{Cl}$, confidence interval; HR, hazard ratio; NS, not significant; RFS, relapse-free survival.

studies. Compared with the few studies using cDNA array technology to identify molecular markers of tamoxifen resistance, we did not find any overlap between the 47-gene signature of tamoxifen resistance identified and the molecular markers previously identified in the few studies available [13,39-42]. Only one gene (FLT1) identified here was present in the 70-gene prognostic signature selected by van't Veer and colleagues [11]. These differences could be due to technical differences in the cDNA array platforms, to the methods of analysis used in each study, or (most probably) to patient inclusion criteria. Fan and colleagues [43] compared the predictions derived from five gene expression profiling studies, and the resulting analysis suggested that even though there was little gene overlap between the different studies, the outcome predictions were similar and probably tracked the same phenotype, illustrated by the same functional clusters.

Among the functional clusters identified in the present study, $34 \%$ of the selected genes encode proteins that are involved in immune response, and most of these genes (88\%) were under-expressed in the TF group. In accordance with our findings, three other gene expression profiling studies also identified low expression mRNA levels of 'immune response' genes in tamoxifen-resistant tumor samples $[13,41,42]$. Such downregulations could allow tamoxifen-resistant cells to escape cell death induced by the immune system (for example, cytotoxic $T$ lymphocytes or natural killers cells), or these observations may be a consequence of a modification of the cellular microenvironment in the tamoxifen-resistant tumor samples. However, the dispersal of neoplastic and lymphocyte cells among stromal tissues make this difficult to assess by cDNA array or RTQ-PCR techniques (even with microdissection), but they may be more amenable to the immunohistochemistry approach.

Apart from the 'immune response' cluster, the 'proliferation' cluster is frequently represented in gene expression signa- tures associated with poor prognosis in breast cancer $[15,44,45]$ or in tamoxifen-treated breast cancer $[40,42]$. In the present study, $23 \%$ of our 47 -gene expression signature also belonged to the proliferation cluster and included IGFBP4, MET, and SNCG.

Many investigators have also considered the expression of estrogen-regulated or estrogen-associated genes, because they could provide valuable prognostic or predictive markers of ER-positive breast cancers $[32,33,39,45]$. In the gene signatures previously identified in tamoxifen-resistant breast carcinoma, $23 \%$ to $50 \%$ of the genes had been related to estrogens, either as ER targets or ER regulators [13,40,42]. In the present study, $36 \%$ of our 47 -gene expression signature associated with tamoxifen failure was related to estrogen action, possibly indicating deregulation of the estrogen signaling pathway. Finally, when compared to the chromosomal distribution of all the genes present on the cDNA arrays used in this study, the chromosomal distribution of the 47 selected genes exhibited a significant $(P<0.05)$ over-representation of genes located on chromosomes $6,11,17$, and 19 (data not shown). Of the 47 genes, $43 \%$ were found to be localized to six specific cytobands (6p21, 11q13, 11q23, 17q11-q21, 19p13, and 19q13). Genetic events located on specific cytobands have previously been identified as associated with tamoxifen resistance $[13,41,46]$, and markers for high-level amplification and/or deregulation of expression of genes at $11 q 13$ and $17 q 12$ were strong predictors of reduced survival in breast cancer [47]. Taken together, these observations suggest that deregulation of expression could be associated with genetic alterations that may occur at specific chromosomal loci in the development of tamoxifen resistance.

Based on the results obtained from the cross-analysis of three different statistical analyses performed on the cDNA array data, ESR1/ER $\alpha$ emerged as the premier gene, in accordance with its well established prognostic and predictive value for 

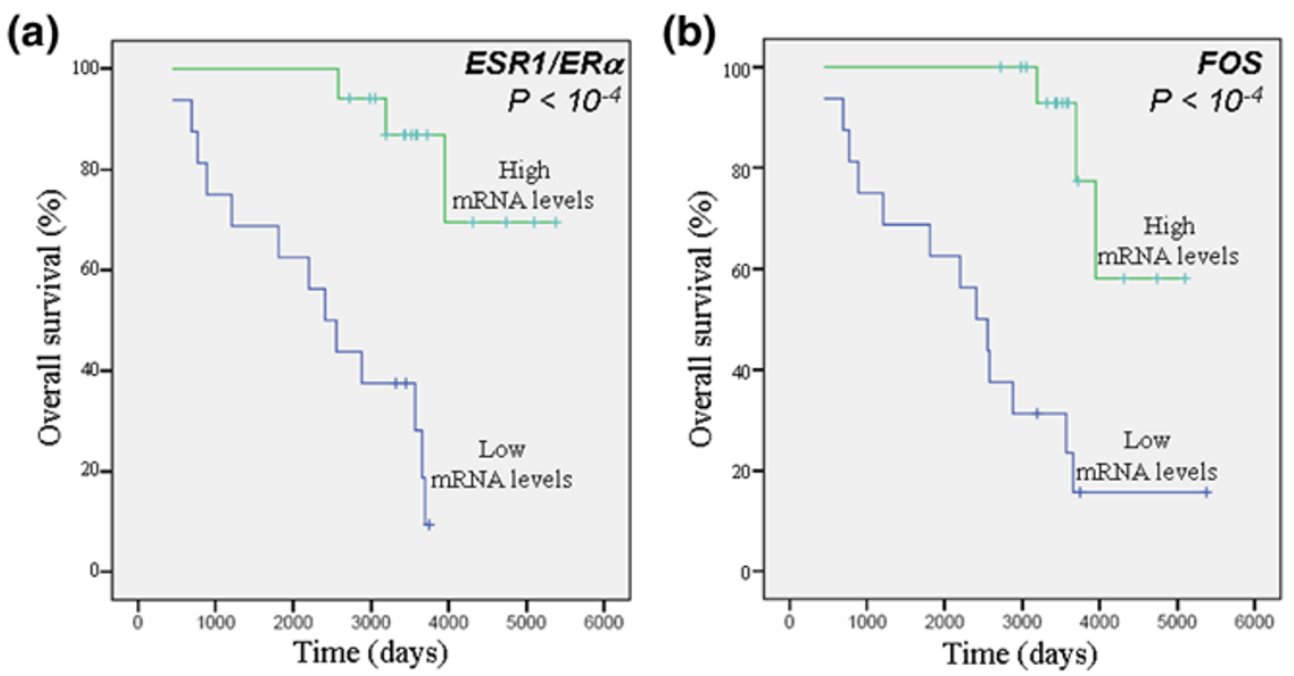

(c)

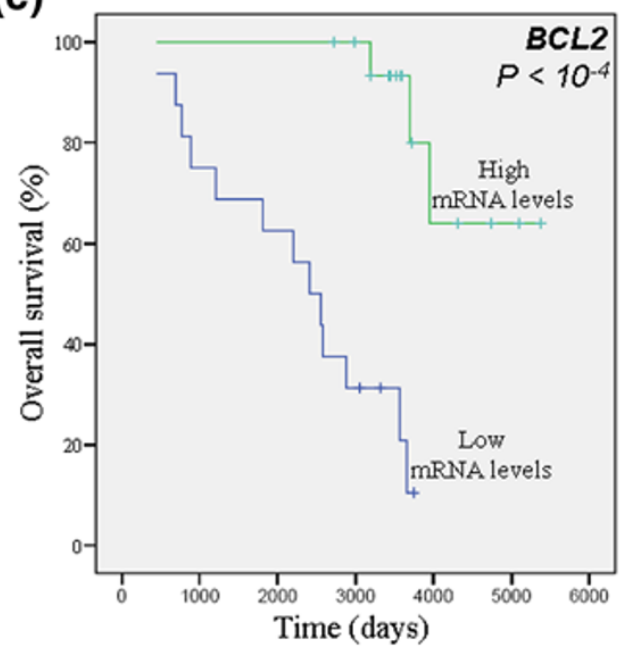

(e)

(d)

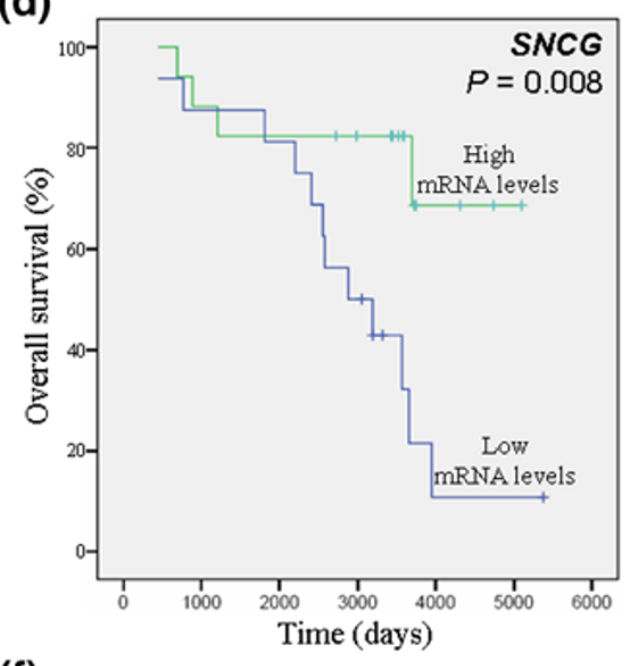

(f)
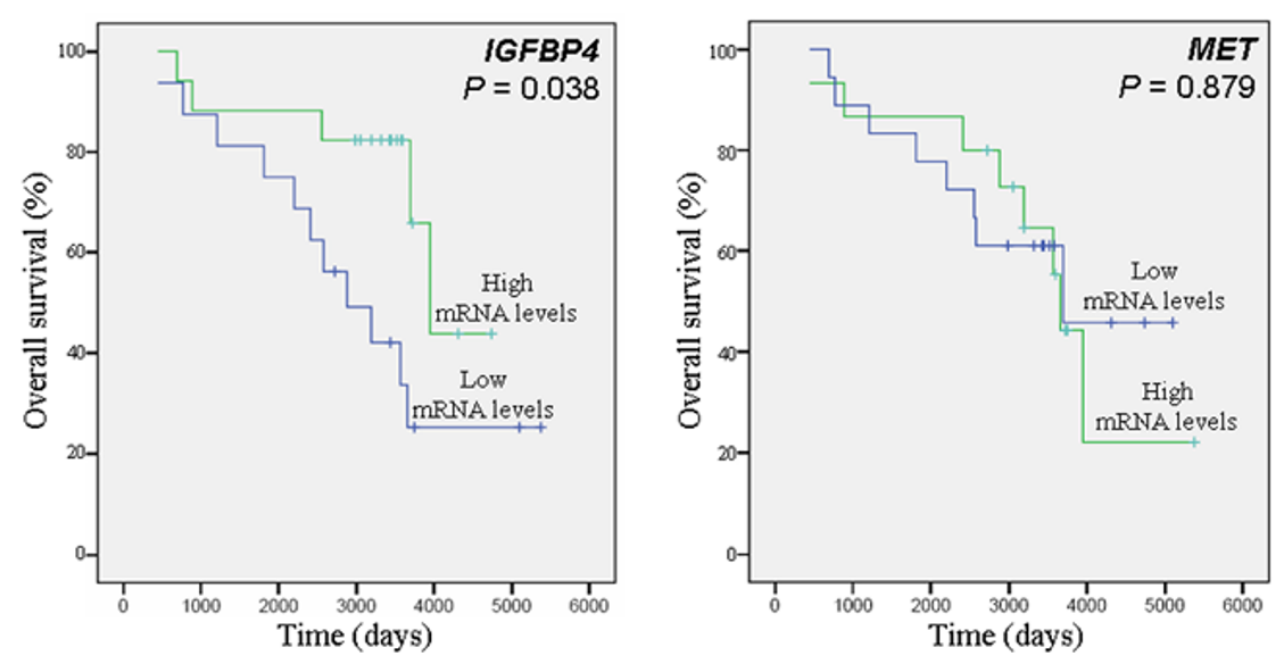

Overall survival. Presented are Kaplan-Meier curves (log-rank test analysis) of breast cancer samples from the Centre Léon Bérard cohort. Effect of (a) ESR1/ERo, (b) FOS, (c) BCL2, (d) SNCG, (e) IGFBP4, and (f) MET mRNA levels on overall survival among the 33 breast cancer samples. 
(a)

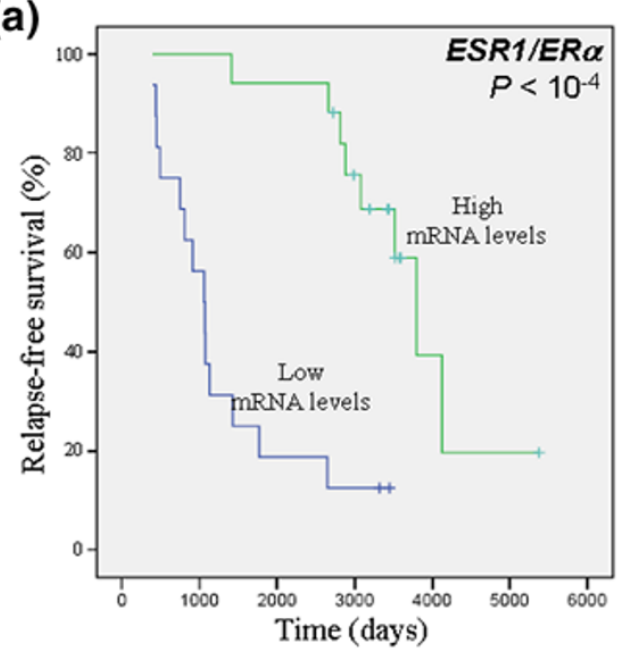

(c)

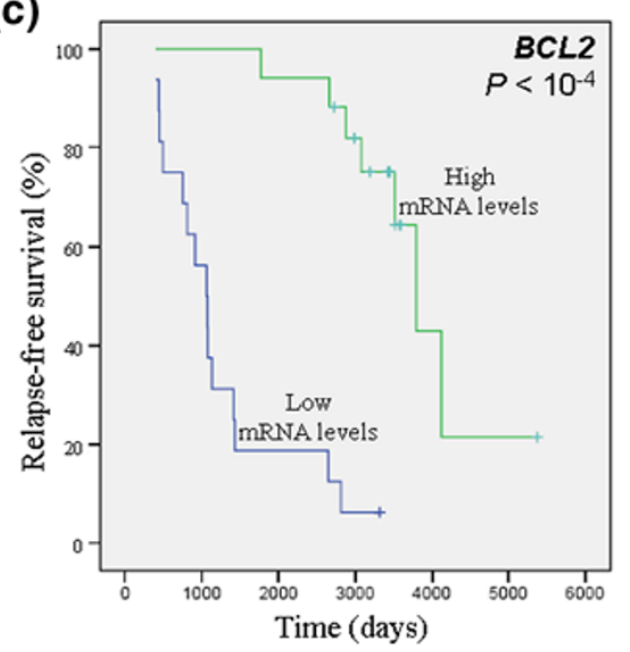

(e)

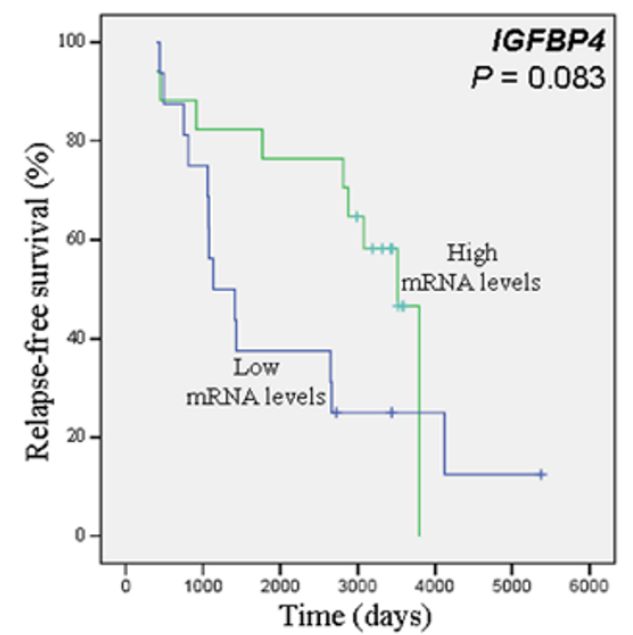

(b)

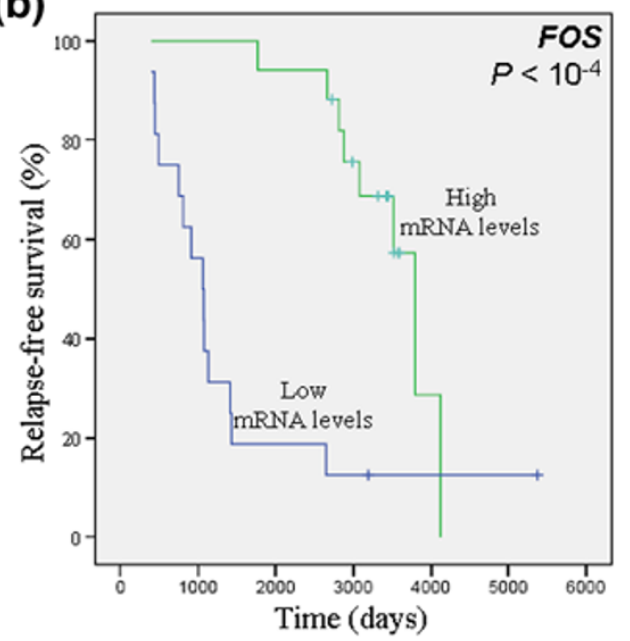

(d)

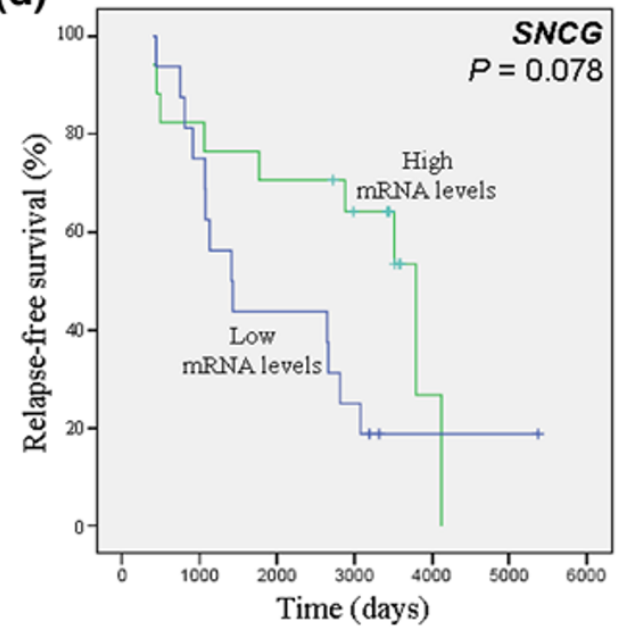

(f)

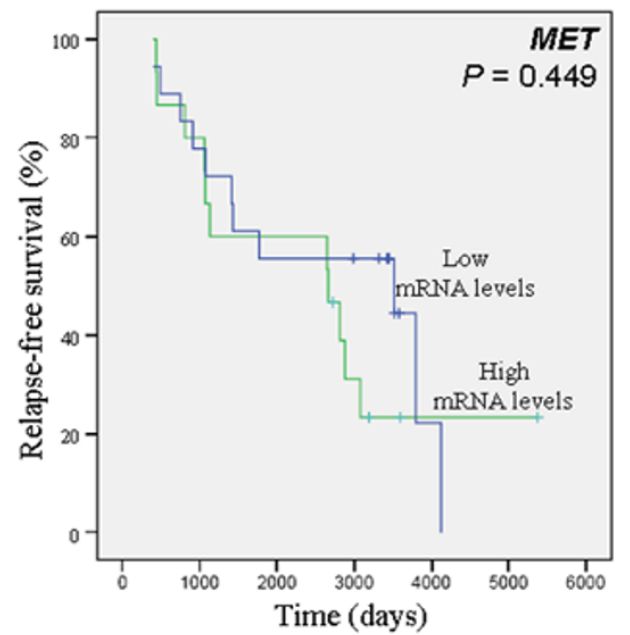

Relapse-free survival. Presented are Kaplan-Meier curves (log-rank test analysis) of breast cancer samples from the Centre Léon Bérard cohort. Effect of (a) ESR1/ERo, (b) FOS, (c) BCL2, (d) SNCG, (e) IGFBP4, and (f) MET mRNA levels on relapse-free survival among the 33 breast cancer samples. 
Figure 5

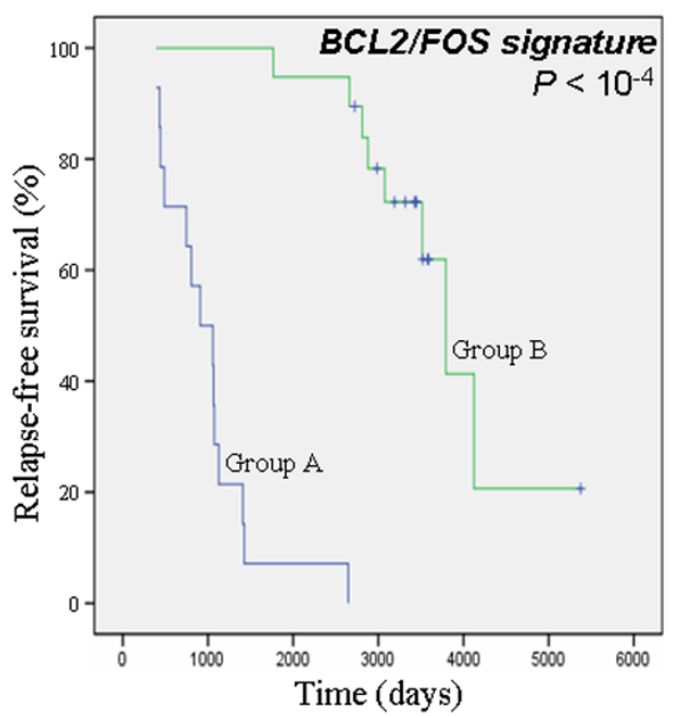

Effect of $B C L 2 / F O S$ signature on relapse-free survival. Shown is the effect of the BCL2/FOS signature on relapse-free survival (KaplanMeier curves, log-rank test analysis) among the Centre Léon Bérard cohort. Group A $(n=14)$ contains the breast cancer samples expressing low mRNA levels of both BCL2 and FOS. Group B $(n=19)$ is composed of the breast cancer samples with high expression levels of at least one of these two genes.

endocrine therapy in breast cancer [35-38], and reinforced the gene signature identified in this study. Among the five following top-ranked genes (MET, FOS, SNCG, IGFBP4, and $B C L 2)$, all were validated by RTQ-PCR experiments. However, only two (IGFBP4 and SNCG) of these five genes were confirmed at the protein level using immunohistochemistry, suggesting first (as observed by others) that the mRNA levels are not always correlated with protein levels, and second that the prognostic/predictive value of a given biomarker can differ with the molecular level investigated (mRNA or protein) $[48,49]$. In an independent cohort used to assess the pertinence of the biomarkers identified, low mRNAs levels of $E S R 1 / E R \alpha$ but also of FOS, BCL2, SNCG, and IGFBP4 were significantly associated with tamoxifen failure. The data obtained with the second cohort added new information, indicating that gene expression differences may be inherent to a primary breast tumor before endocrine therapy and might not only reflect deregulation of expression induced by tamoxifen exposure.

Among the six top-ranked genes, this study allowed identification of reduced expression of FOS associated with tamoxifen failure. Interestingly, in our cDNA array experiments, two other members of the activator protein-1 complex, namely JUN and $J U N B$, were also expressed to lesser degrees in tamoxifenresistant tumors than in control tumors. MET over-expression may be linked to poor clinical outcome in patients with breast cancer [50,51]. High BCL2 tumor expression was associated with better outcome in endocrine-treated breast cancers [5256]. High levels of SNCG (also called BCSG1 [breast cancerspecific gene 1]) have been identified in advanced breast carcinomas $[57,58]$ and associated with poor clinical outcome [59]. Recently reported data also demonstrated the role played by SNCG as an ER chaperone and modulator of ER signaling, suggesting that SNCG strongly contributes to the tumorigenesis of ER-positive breast cancer [60], providing evidence for crosstalk between SNCG and ER signaling. IGFBP4 is a member of the IGFBP proteins and appears to be a potent inhibitor of insulin-like growth factor function in several cell lines [61-63]. IGFBP4, an estrogen-regulated gene $[15,64]$, is downregulated in tamoxifen-resistant cell lines [65], forms part of a molecular signature of poor prognosis ER-positive breast cancer [32], and could help to identify people who may benefit from endocrine therapy in ovarian cancer [66]. A recent study also revealed that IGFBP 4 mRNA expression is an independent prognostic factor in breast cancer, and that patients with ER-positive breast cancer with higher levels of IGFBP4 tumor mRNA expression and lower levels of IGFBP5 mRNA had a better prognosis [67]. However, the number of patients treated with endocrine therapy in that study was too limited to evaluate the predictive value of IGFBP4 for endocrine therapy responsiveness.

When assessing the prognostic significance of the markers identified, our analysis revealed several marker dependencies and interactions. For example, although ESR1/ER $\alpha, F O S$, and $B C L 2$ were significant univariate factors for RFS, only FOS and $B C L 2$ emerged as independent prognostic factors in multivariate analysis. In a previous study, reduced FOS gene expression levels were associated with high histologic grade in breast tumors [68]. However, to our knowledge, no study has described any prognostic or predictive value of FOS in endocrine-treated patients. A previous immunohistochemistry study suggested that $\mathrm{Bcl} 2$ is an independent predictor of breast cancer outcome [69]. In tamoxifen-treated ER-positive patients, low $\mathrm{Bcl} 2$ protein expression levels are associated with worse outcome [52-56], and independent prognostic value of $\mathrm{Bcl} 2$ protein alone was observed in two studies [54,56]. BCL2 and FOS are known to be estrogen-regulated genes [15,33,70,71], and we observed in our study a significant positive correlation (Spearman rank correlation test) between ESR1/ER $\alpha$ mRNA levels and BCL2 $(P<0.0002)$ or FOS $(P<0.01)$ mRNA levels, both in the first and second cohort of patients (data not shown). Thus, high BCL2 levels and/or high FOS levels may only reflect aggressiveness of the disease or may be indicative of an intact pathway that is driving tumor growth and that should be sensitive to endocrine therapy. This raises the issue of whether the prognostic value for RFS of the BCL2/FOS signature is more accurate than ESR1/ $E R \alpha$ mRNA levels. In this study, statistical analysis clearly demonstrated that BCL2 alone was more informative than ESR1/ER $\alpha$ mRNA levels, and that combination of BCL2 with 
FOS in a two-gene signature increased the prognostic value of $B C L 2$. These data suggest that the biomarkers identified in this study may represent candidate markers that could help in stratifying ER-positive patients, facilitating selection of therapy.

\section{Conclusions}

In this study we identified a gene expression signature and molecular markers associated with tamoxifen failure in breast cancer. RTQ-PCR may provide the best quantitative measure of IGFBP4, BCL2, FOS, SNCG, and MET, particularly because this technology is in common use in clinical laboratories and could be applied to fine needle aspiration biopsy samples taken sequentially during treatment. Validation at the protein level of SNCG and IGFBP4 using TMAs demonstrated that immunohistochemistry of these proteins may be pursued in the future as a therapeutic decision making tool. Moreover, molecular markers encoding secreted proteins such as IGFBP4, which was validated in this study both by RTQ-PCR and immunohistochemistry, are interesting because they may be investigated in the future in patient serum and offer therapeutic potential. Finally, the low expression levels of ESR1/ $E R \alpha$, FOS, BCL2, SNCG, and IGFBP4 were found to be associated with poor prognosis in an independent cohort of patients exhibiting tamoxifen failure. We also demonstrated the strong prognostic value of the BCL2/FOS signature in ERpositive patients who relapsed under tamoxifen treatment.

To conclude, the present exploratory study identified new biomarkers of tamoxifen failure that could be helpful in clinical decision making in patients with endocrine-dependant breast cancer. Because the biomarkers identified in this study were confirmed in two independent patient groups, differences between the two cohorts from different geographic location (Ninewells Hospital and Centre Léon Bérard) is unlikely to have influenced the gene signature. However, further work is needed to evaluate the prognostic and/or predictive value of these biomarkers in prospective studies using larger cohorts of patients.

\section{Competing interests}

The authors declare that they have no competing interests.

\section{Authors' contributions}

JAV conducted the transcriptome study, performed the RTQPCR experiments, and drafted the manuscript. KER, SMH, and CAP conducted the TMA experiments. PR set up and conducted the $\mathrm{K}$ nearest neighbor method, and performed the statistical analyses. SEB performed RNA extraction of patient samples and conducted the TMA experiments. AB and SC performed part of the statistical analyses on the validation cohort of tumor samples. CN helped to set up the cDNA array technology. IB helped in the RTQ-PCR investigation. TB selected patients from the Centre Léon Bérard database (Lyon, France). AMT and PAC conceived of the study, its design and coordination, and drafted the manuscript. All authors read and approved the final manuscript.

\section{Acknowledgements}

This work was supported by grants from the Entente Cordiale Program (France/UK), the French Ligue Nationale Contre le Cancer (Comité de I'Ardèche, Comité de la Saône et Loire, Comité de Savoie), the ARC (Association pour la Recherche contre le Cancer), and Breast Cancer Research Scotland. JAV was supported by fellowships from the Ligue Nationale Contre le Cancer (France) and Breast Cancer Research Scotland. SMH was also supported by Breast Cancer Research Scotland. The Dundee Tissue Bank was supported by MRC, CRUK, NTRAC, and Breast Cancer Research Scotland. We are grateful to the Centre de Ressource Biologique of the Centre Léon Bérard for providing tumor samples for the independent cohort. We also thank Dr JC Bourdon for help with the statistical analyses and Professor C Dumontet for access to the LightCycler $480^{\circledR}$.

\section{References}

1. Ferlay J, Bray F, Pisani P, Parkin DM: Globocan 2002: Cancer Incidence, Mortality and Prevalence Worldwide Lyon, France: IARC Press; 2004.

2. Veronesi U, Boyle P, Goldhirsch A, Orecchia R, Viale G: Breast cancer. Lancet 2005, 365:1727-1741.

3. EBCTC Group: Effects of chemotherapy and hormonal therapy for early breast cancer on recurrence and 15-year survival: an overview of the randomised trials. Lancet 2005, 365:1687-1717.

4. Horobin JM, Preece PE, Dewar JA, Wood RA, Cuschieri A: Longterm follow-up of elderly patients with locoregional breast cancer treated with tamoxifen only. $B r J$ Surg 1991, 78:213-217.

5. Fennessy M, Bates T, MacRae K, Riley D, Houghton J, Baum M: Late follow-up of a randomized trial of surgery plus tamoxifen versus tamoxifen alone in women aged over 70 years with operable breast cancer. Br J Surg 2004, 91:699-704.

6. Wolmark N, Dunn BK: The role of tamoxifen in breast cancer prevention: issues sparked by the NSABP Breast Cancer Prevention Trial (P-1). Ann N Y Acad Sci 2001, 949:99-108.

7. Perou CM, Sorlie T, Eisen MB, Rijn M van de, Jeffrey SS, Rees CA, Pollack JR, Ross DT, Johnsen H, Akslen LA, Fluge O, Pergamenschikov $A$, Williams $C$, Zhu SX, Lønning PE, Børresen-Dale AL, Brown PO, Botstein D: Molecular portraits of human breast tumours. Nature 2000, 406:747-752.

8. Sorlie T, Perou CM, Tibshirani R, Aas T, Geisler S, Johnsen H, Hastie T, Eisen MB, Rijn M van de, Jeffrey SS, Thorsen T, Quist $H$, Matese JC, Brown PO, Botstein D, Eystein Lønning P, BørresenDale AL: Gene expression patterns of breast carcinomas distinguish tumor subclasses with clinical implications. Proc Nat/ Acad Sci USA 2001, 98:10869-10874.

9. Dai H, van't Veer L, Lamb J, He YD, Mao M, Fine BM, Bernards R, Vijver M van de, Deutsch P, Sachs A, Stoughton R, Friend S: A cell proliferation signature is a marker of extremely poor outcome in a subpopulation of breast cancer patients. Cancer Res 2005, 65:4059-4066

10. Vijver MJ van de, He YD, van't Veer LJ, Dai H, Hart AA, Voskuil DW, Schreiber GJ, Peterse JL, Roberts C, Marton MJ, Parrish M, Atsma D, Witteveen A, Glas A, Delahaye L, Velde T van der, Bartelink H, Rodenhuis S, Rutgers ET, Friend SH, Bernards R: A geneexpression signature as a predictor of survival in breast cancer. N Engl J Med 2002, 347:1999-2009.

11. van't Veer LJ, Dai H, Vijver MJ van de, He YD, Hart AA, Mao M, Peterse HL, Kooy K van der, Marton MJ, Witteveen AT, Schreiber GJ, Kerkhoven RM, Roberts C, Linsley PS, Bernards R, Friend SH: Gene expression profiling predicts clinical outcome of breast cancer. Nature 2002, 415:530-536.

12. Chang JC, Wooten EC, Tsimelzon A, Hilsenbeck SG, Gutierrez MC, Elledge R, Mohsin S, Osborne CK, Chamness GC, Allred DC, O'Connell P: Gene expression profiling for the prediction of therapeutic response to docetaxel in patients with breast cancer. Lancet 2003, 362:362-369. 
13. Jansen MP, Foekens JA, van Staveren IL, Dirkzwager-Kiel MM, Ritstier K, Look MP, Meijer-van Gelder ME, Sieuwerts AM, Portengen $H$, Dorssers LC, Klijn JG, Berns EM: Molecular classification of tamoxifen-resistant breast carcinomas by gene expression profiling. J Clin Oncol 2005, 23:732-740.

14. Bertucci F, Van Hulst S, Bernard K, Loriod B, Granjeaud S, Tagett $R$, Starkey M, Nguyen C, Jordan B, Birnbaum D: Expression scanning of an array of growth control genes in human tumor cell lines. Oncogene 1999, 18:3905-3912.

15. Vendrell JA, Magnino F, Danis E, Duchesne MJ, Pinloche S, Pons M, Birnbaum D, Nguyen C, Theillet C, Cohen PA: Estrogen regulation in human breast cancer cells of new downstream gene targets involved in estrogen metabolism, cell proliferation and cell transformation. J Mol Endocrinol 2004, 32:397-414.

16. Vendrell JA, Bieche I, Desmetz C, Badia E, Tozlu S, Nguyen C, Nicolas JC, Lidereau R, Cohen PA: Molecular changes associated with the agonist activity of hydroxy-tamoxifen and the hyper-response to estradiol in hydroxy-tamoxifen-resistant breast cancer cell lines. Endocr Relat Cancer 2005, 12:75-92.

17. Lopez F, Rougemont J, Loriod B, Bourgeois A, Loi L, Bertucci F, Hingamp $P$, Houlgatte R, Granjeaud S: Feature extraction and signal processing for nylon DNA microarrays. BMC Genomics 2004, 5:38.

18. Ramaswamy S, Ross KN, Lander ES, Golub TR: A molecular signature of metastasis in primary solid tumors. Nat Genet 2003, 33:49-54.

19. Tusher VG, Tibshirani R, Chu G: Significance analysis of microarrays applied to the ionizing radiation response. Proc Natl Acad Sci USA 2001, 98:5116-5121.

20. Eisen MB, Spellman PT, Brown PO, Botstein D: Cluster analysis and display of genome-wide expression patterns. Proc Natl Acad Sci USA 1998, 95:14863-14868.

21. Detre S, Saclani Jotti G, Dowsett M: A 'quickscore' method for immunohistochemical semiquantitation: validation for oestrogen receptor in breast carcinomas. J Clin Pathol 1995, 48:876-878.

22. Cox DR: Regression models and life tables. J R Stat Soc Ser B Stat Methodol 1972, 34:187-220.

23. Harrell FE: Regression modeling strategies. Springer Publishing Company, New York, NY, USA; 2001.

24. Cicatiello L, Scafoglio C, Altucci L, Cancemi M, Natoli G, Facchiano A, lazzetti G, Calogero R, Biglia N, De Bortoli M, Bortoli M, Sfiligoi $C$, Sismondi $P$, Bresciani $F$, Weiz $A$ : A genomic view of estrogen actions in human breast cancer cells by expression profiling of the hormone-responsive transcriptome. $\mathrm{J} \mathrm{Mol}$ Endocrinol 2004, 32:719-775.

25. Finlin BS, Gau CL, Murphy GA, Shao H, Kimel T, Seitz RS, Chiu YF, Botstein D, Brown PO, Der CJ, Tamanoi F, Andres DA, Perou $\mathrm{CM}$ : RERG is a novel ras-related, estrogen-regulated and growth-inhibitory gene in breast cancer. J Biol Chem 2001, 276:42259-42267.

26. Frasor J, Danes JM, Komm B, Chang KC, Lyttle CR, Katzenellenbogen BS: Profiling of estrogen up- and down-regulated gene expression in human breast cancer cells: insights into gene networks and pathways underlying estrogenic control of proliferation and cell phenotype. Endocrinology 2003, 144:4562-4574.

27. Leung LK, Wang TT: Paradoxical regulation of Bcl-2 family proteins by 17 beta-oestradiol in human breast cancer cells MCF7. Br J Cancer 1999, 81:387-392.

28. Lin CY, Strom A, Vega VB, Kong SL, Yeo AL, Thomsen JS, Chan WC, Doray B, Bangarusamy DK, Ramasamy A, Vergara LA, Tang S, Chong A, Bajic VB, Miller LD, Gustafsson JA, Liu ET: Discovery of estrogen receptor alpha target genes and response elements in breast tumor cells. Genome Biol 2004, 5:R66.

29. Pusztai L, Ayers M, Stec J, Clark E, Hess K, Stivers D, Damokosh A, Sneige N, Buchholz TA, Esteva FJ, Arun B, Cristofanilli M, Booser D, Rosales M, Valero V, Adams C, Hortobagyi GN, Symmans WF: Gene expression profiles obtained from fine-needle aspirations of breast cancer reliably identify routine prognostic markers and reveal large-scale molecular differences between estrogen-negative and estrogen-positive tumors. Clin Cancer Res 2003, 9:2406-2415.

30. Soulez M, Parker MG: Identification of novel oestrogen receptor target genes in human ZR75-1 breast cancer cells by expression profiling. J Mol Endocrinol 2001, 27:259-274.
31. Jensen BL, Skouv J, Lundholt BK, Lykkesfeldt AE: Differential regulation of specific genes in MCF-7 and the ICI 182780-resistant cell line MCF-7/182R-6. Br J Cancer 1999, 79:386-392.

32. Yoshida N, Omoto Y, Inoue A, Eguchi H, Kobayashi Y, Kurosumi M, Saji S, Suemasu K, Okazaki T, Nakachi K, Fujita T, Hayashi S: Prediction of prognosis of estrogen receptor-positive breast cancer with combination of selected estrogen-regulated genes. Cancer Sci 2004, 95:496-502.

33. Frasor J, Chang EC, Komm B, Lin CY, Vega VB, Liu ET, Miller LD, Smeds J, Bergh J, Katzenellenbogen BS: Gene expression preferentially regulated by tamoxifen in breast cancer cells and correlations with clinical outcome. Cancer Res 2006, 66:7334-7340.

34. Tozlu S, Girault I, Vacher S, Vendrell J, Andrieu C, Spyratos F, Cohen P, Lidereau R, Bieche I: Identification of novel genes that co-cluster with estrogen receptor alpha in breast tumor biopsy specimens, using a large-scale real-time reverse transcription-PCR approach. Endocr Relat Cancer 2006, 13:1109-1120.

35. Henry JA, Nicholson S, Farndon JR, Westley BR, May FE: Measurement of oestrogen receptor mRNA levels in human breast tumours. Br J Cancer 1988, 58:600-605.

36. Pichon MF, Broet P, Magdelenat H, Delarue JC, Spyratos F, Basuyau JP, Saez S, Rallet A, Courriere P, Millon R, Asselain B: Prognostic value of steroid receptors after long-term follow-up of 2257 operable breast cancers. $\mathrm{Br} J$ Cancer 1996, 73:1545-1551.

37. Ferno M, Stal O, Baldetorp B, Hatschek T, Kallstrom AC, Malmstrom $\mathrm{P}$, Nordenskjold B, Ryden S: Results of two or five years of adjuvant tamoxifen correlated to steroid receptor and Sphase levels. South Sweden Breast Cancer Group, and SouthEast Sweden Breast Cancer Group. Breast Cancer Res Treat 2000, 59:69-76.

38. Nardelli GB, Lamaina V, Siliotti F: Estrogen and progesterone receptors status in the prediction of response of breast cancer to endocrine therapy (preliminary report). Eur J Gynaecol Oncol 1986, 7:151-158.

39. Tozlu-Kara S, Roux V, Andrieu C, Vendrell J, Vacher S, Lazar V, Spyratos F, Tubiana-Hulin M, Cohen P, Dessen P, Lidereau R, Bièche I: Oligonucleotide microarray analysis of estrogen receptor alpha-positive postmenopausal breast carcinomas: identification of HRPAP20 and TIMELESS as outstanding candidate markers to predict the response to tamoxifen. $J \mathrm{Mol}$ Endocrinol 2007, 39:305-318.

40. Becker M, Sommer A, Kratzschmar JR, Seidel H, Pohlenz HD, Fichtner I: Distinct gene expression patterns in a tamoxifensensitive human mammary carcinoma xenograft and its tamoxifen-resistant subline MaCa 3366/TAM. Mol Cancer Ther $2005,4: 151-168$.

41. Ma XJ, Wang Z, Ryan PD, Isakoff SJ, Barmettler A, Fuller A, Muir B, Mohapatra G, Salunga R, Tuggle JT, Tran Y, Tran D, Tassin A, Amon $\mathrm{P}$, Wang W, Wang W, Enright E, Stecker K, Estepa-Sabal E, Smith B, Younger J, Balis U, Michaelson J, Bhan A, Habin K, Baer TM, Brugge J, Haber DA, Erlander MG, Sgroi DC: A twogene expression ratio predicts clinical outcome in breast cancer patients treated with tamoxifen. Cancer Cell 2004 5:607-616.

42. Chanrion $M$, Negre $V$, Fontaine $H$, Salvetat $N$, Bibeau F, Mac Grogan G, Mauriac L, Katsaros D, Molina F, Theillet C, Darbon JM: A gene expression signature that can predict the recurrence of tamoxifen-treated primary breast cancer. Clin Cancer Res 2008, 14:1744-1752.

43. Fan C, Oh DS, Wessels L, Weigelt B, Nuyten DS, Nobel AB, van't Veer LJ, Perou CM: Concordance among gene-expressionbased predictors for breast cancer. N Engl J Med 2006, 355:560-569.

44. Sotiriou C, Wirapati P, Loi S, Harris A, Fox S, Smeds J, Nordgren $H$, Farmer P, Praz V, Haibe-Kains B, Desmedt C, Larsimont D, Cardoso F, Peterse H, Nuyten D, Buyse M, Vijver MJ Van de, Bergh J, Piccart M, Delorenzi M: Gene expression profiling in breast cancer: understanding the molecular basis of histologic grade to improve prognosis. J Natl Cancer Inst 2006, 98:262-272.

45. Oh DS, Troester MA, Usary J, Hu Z, He X, Fan C, Wu J, Carey LA, Perou CM: Estrogen-regulated genes predict survival in hormone receptor-positive breast cancers. J Clin Oncol 2006 24:1656-1664.

46. Achuthan R, Bell SM, Roberts $P$, Leek JP, Horgan $K$, Markham AF, MacLennan KA, Speirs V: Genetic events during the transfor- 
mation of a tamoxifen-sensitive human breast cancer cell line into a drug-resistant clone. Cancer Genet Cytogenet 2001, 130:166-172.

47. Chin SF, Wang Y, Thorne NP, Teschendorff AE, Pinder SE, Vias M, Naderi A, Roberts I, Barbosa-Morais NL, Garcia MJ, lyer NG, Kranjac T, Robertson JF, Aparicio S, Tavaré S, Ellis I, Brenton JD, Caldas C: Using array-comparative genomic hybridization to define molecular portraits of primary breast cancers. Oncogene 2007, 26:1959-1970.

48. Milde-Langosch $\mathrm{K}$, Kappes $\mathrm{H}$, Riethdorf $\mathrm{S}$, Loning $\mathrm{T}$, Bamberger AM: FosB is highly expressed in normal mammary epithelia, but down-regulated in poorly differentiated breast carcinomas. Breast Cancer Res Treat 2003, 77:265-275.

49. Vinayagam R, Sibson DR, Holcombe C, Aachi V, Davies MP: Association of oestrogen receptor beta 2 (ER beta 2/ER beta cx) with outcome of adjuvant endocrine treatment for primary breast cancer: a retrospective study. BMC Cancer 2007, 7:131.

50. Ghoussoub RA, Dillon DA, D'Aquila T, Rimm EB, Fearon ER, Rimm $\mathrm{DL}$ : Expression of $\mathrm{c}$-met is a strong independent prognostic factor in breast carcinoma. Cancer 1998, 82:1513-1520.

51. Lengyel E, Prechtel D, Resau JH, Gauger K, Welk A, Lindemann K, Salanti G, Richter T, Knudsen B, Woude GF Vande, Harbeck N: C-Met overexpression in node-positive breast cancer identifies patients with poor clinical outcome independent of Her2/ neu. Int J Cancer 2005, 113:678-682.

52. Gasparini G, Barbareschi M, Doglioni C, Palma PD, Mauri FA, Boracchi P, Bevilacqua P, Caffo O, Morelli L, Verderio P, Pezzella $\mathrm{F}$, Harris AL: Expression of bcl-2 protein predicts efficacy of adjuvant treatments in operable node-positive breast cancer. Clin Cancer Res 1995, 1:189-198.

53. Silvestrini $R$, Benini $E$, Veneroni $S$, Daidone MG, Tomasic $G$ Squicciarini $P$, Salvadori B: $p 53$ and bcl-2 expression correlates with clinical outcome in a series of node-positive breast cancer patients. J Clin Oncol 1996, 14:1604-1610.

54. Elledge RM, Green S, Howes L, Clark GM, Berardo M, Allred DC, Pugh R, Ciocca D, Ravdin P, O'Sullivan J, Rivkin S, Martino S, Osborne CK: bcl-2, p53, and response to tamoxifen in estrogen receptor-positive metastatic breast cancer: a Southwest Oncology Group study. J Clin Oncol 1997, 15:1916-1922.

55. Linke SP, Bremer TM, Herold CD, Sauter G, Diamond C: A multimarker model to predict outcome in tamoxifen-treated breast cancer patients. Clin Cancer Res 2006, 12:1175-1183.

56. Trere D, Montanaro L, Ceccarelli C, Barbieri S, Cavrini G, Santini $D$, Taffurelli M, Derenzini M: Prognostic relevance of a novel semiquantitative classification of $\mathrm{Bcl} 2$ immunohistochemical expression in human infiltrating ductal carcinomas of the breast. Ann Oncol 2007, 18:1004-1014.

57. Ji H, Liu YE, Jia T, Wang M, Liu J, Xiao G, Joseph BK, Rosen C, Shi YE: Identification of a breast cancer-specific gene, BCSG1, by direct differential cDNA sequencing. Cancer Res 1997, 57:759-764.

58. Wu K, Weng Z, Tao Q, Lin G, Wu X, Qian H, Zhang Y, Ding X, Jiang $Y$, Shi $Y E$ : Stage-specific expression of breast cancerspecific gene gamma-synuclein. Cancer Epidemiol Biomarkers Prev 2003, 12:920-925

59. Guo J, Shou C, Meng L, Jiang B, Dong B, Yao L, Xie Y, Zhang J, Chen Y, Budman DR, Shi YE: Neuronal protein synuclein gamma predicts poor clinical outcome in breast cancer. Int $J$ Cancer 2007, 121:1296-1305.

60. Liu YE, Pu W, Jiang Y, Shi D, Dackour R, Shi YE: Chaperoning of estrogen receptor and induction of mammary gland proliferation by neuronal protein synuclein gamma. Oncogene 2007, 26:2115-2125.

61. Cheung PT, Smith EP, Shimasaki S, Ling N, Chernausek SD: Characterization of an insulin-like growth factor binding protein (IGFBP-4) produced by the B104 rat neuronal cell line: chemical and biological properties and differential synthesis by sublines. Endocrinology 1991, 129:1006-1015.

62. Kiefer MC, Schmid C, Waldvogel M, Schlapfer I, Futo E, Masiarz FR, Green K, Barr PJ, Zapf J: Characterization of recombinant human insulin-like growth factor binding proteins 4,5 , and 6 produced in yeast. J Biol Chem 1992, 267:12692-12699.

63. Neely EK, Rosenfeld RG: Insulin-like growth factors (IGFs) reduce IGF-binding protein-4 (IGFBP-4) concentration and stimulate IGFBP-3 independently of IGF receptors in human fibroblasts and epidermal cells. Endocrinology 1992, 130:985-993.

64. Inoue A, Yoshida N, Omoto Y, Oguchi S, Yamori T, Kiyama R, Hayashi S: Development of cDNA microarray for expression profiling of estrogen-responsive genes. J Mol Endocrinol 2002, 29:175-192.

65. Maxwell $\mathrm{P}$, Berg HW van den: Changes in the secretion of insulin-like growth factor binding proteins -2 and -4 associated with the development of tamoxifen resistance and estrogen independence in human breast cancer cell lines. Cancer Lett 1999, 139:121-127.

66. Walker G, MacLeod K, Williams AR, Cameron DA, Smyth JF, Langdon SP: Insulin-like growth factor binding proteins IGFBP3 IGFBP4, and IGFBP5 predict endocrine responsiveness in patients with ovarian cancer. Clin Cancer Res 2007, 13:1438-1444.

67. Mita K, Zhang Z, Ando Y, Toyama T, Hamaguchi M, Kobayashi S, Hayashi S, Fujii Y, Iwase H, Yamashita H: Prognostic significance of insulin-like growth factor binding protein (IGFBP)-4 and IGFBP-5 expression in breast cancer. Jpn J Clin Oncol 2007, 37:575-582.

68. Ivshina AV, George J, Senko O, Mow B, Putti TC, Smeds J, Lindah $T$, Pawitan $Y$, Hall $P$, Nordgren $H$, Wong JE, Liu ET, Bergh J, Kuznetsov VA, Miller LD: Genetic reclassification of histologic grade delineates new clinical subtypes of breast cancer. Cancer Res 2006, 66:10292-10301.

69. Callagy GM, Pharoah PD, Pinder SE, Hsu FD, Nielsen TO, Ragaz $\mathrm{J}$, Ellis IO, Huntsman D, Caldas C: Bcl-2 is a prognostic marker in breast cancer independently of the Nottingham Prognostic Index. Clin Cancer Res 2006 , 12:2468-2475.

70. Perillo B, Sasso A, Abbondanza C, Palumbo G: 17beta-estradiol inhibits apoptosis in MCF-7 cells, inducing bcl-2 expression via two estrogen-responsive elements present in the coding sequence. Mol Cell Biol 2000, 20:2890-2901.

71. Carroll JS, Meyer CA, Song J, Li W, Geistlinger TR, Eeckhoute J, Brodsky AS, Keeton EK, Fertuck KC, Hall GF, Wang Q, Bekiranov $S$, Sementchenko V, Fox EA, Silver PA, Gingeras TR, Liu XS Brown $\mathrm{M}$ : Genome-wide analysis of estrogen receptor binding sites. Nat Genet 2006, 38:1289-1297. 